\title{
The Influence of Website Content on the Purchase of Pharmaceutical Health Products
}

\section{Lernese Jones}

\author{
Department of Marketing, University of the Witwatersrand \\ Email: lernese.jones@gmail.com \\ *Norman Chiliya \\ Department of Marketing, University of the Witwatersrand \\ Email: norman.chiliya@wits.ac.za
}

Doi:10.5901/mjss.2014.v5n25p128

\begin{abstract}
The purpose of this research was to determine what web content, according to the perception of consumers and their purchase behaviour, are optimal for the healthcare industry and also understand which content factors are more important than others. $A$ quantitative, single cross-sectional approach was undertaken. A convenience technique was used. Data was collected from a sample of 362 University students by means self-administered questionnaires. Regression analyses were conducted as means of data analysis. The study shows that consumers are significantly affected by the different types of content components incorporated into a webpage. Within these content components, consumers view quality information as more valuable as they are informed about products more effectively, relevant to their needs. This then influences the consumers' information satisfaction. Once the consumer is satisfied with the information provided through the relevant content components, loyalty towards the firm is developed due to the consistent quality of the content thus, resulting in purchase behaviour. This shows that it is important for online health websites to provide relevant and quality information to in assist consumers in making an online purchase.
\end{abstract}

Keywords: online marketing, Content, Pharmaceutical health products

\section{Introduction}

Internet usage has grown rapidly all over the world (Liebermann \& Stashevsky, 2002). Many businesses today are conducted through the internet as it provides global connectivity and vast opportunities for businesses to break through geographical barriers that traditional businesses may face (Madu \& Madu, 2002). A business conducted online is commonly referred to as an electronic-commerce business whereby, consumers are able to search for product information and make purchases through direct contact with the online store (Park \& Kim, 2003). According to Zwass (1996), 'Electronic commerce is based on sharing business information, maintaining business relationships and conducting business transactions by means of telecommunications networks' (Zwass, 1996, p. 5).

Providing information is the basic goal of the web and whether consumers are searching for products, services, news, weather, travel or entertainment (Huizingh, 2000), there is much competition for consumer attention (Schenkman \& Jonsson, 2000). "Content is king" as stated by Bill Gates (1996), is quite a well-known slogan (Gates, 1996). Website content is the information provided to consumers on the website and takes various forms ranging from basic sites providing customers with general company information to more complex sites where interactive applications provide an array of virtual services, on screen order forms and the opportunity to give feedback (Perry \& Bodkin, 2000; Huizingh, 2000). Website content and information is provided to consumers through online icons referred to as "website content components" (Perry \& Bodkin, 2000). Good content should be attractive, relevant, and suitable for the consumers targeted, as good content is a value-added component and it makes information seeking more convenient for consumers (Ellinger, Lynch, Andzulis, \& Smith, 2003). Although websites contain various content features, the basic goal of a website is to provide information (Huizingh, 2000). Since online shoppers mainly interact with the website and cannot physically touch, feel or experience the actual product, consumers make decisions based mainly on the information provided by the online store (Park \& Kim, 2003) thus, the content provided becomes imperative in purchase decision making.

While different sources may report different numbers of current internet users, common ground exists where all 
reporters agree that internet usage is growing rapidly. De Lanerolle (2012) found out that 34 percent (12,3million) of adults in South Africa aged 15 or older make use of the internet. De Lanerolle (2012) thus concluded that one in three South Africans gain access to the internet through a cell phone (71\%), at home internet access (43\%), work (36\%) and commercial Internet Cafés (33\%). Later, De Lanerolle (2012) predicted that more than half the population will be online by 2014 and at least two-thirds by 2016. According to the survey results, people initially start using the internet to gain knowledge, to connect inexpensively and efficiently and to assist them in their work. One of the top five reasons for going online is information search (De Lanerolle, 2012).

In order to maximize impact and the effectiveness of a website, online presentation should engage with and improve a user's experience (Yates \& Noyes, 2007). With the internet being a main source of information and a major distribution channel, the task of attracting as many customers to a company website as possible becomes highly important. Therefore it is imperative that a website provides content and information consumers seek (Evans \& King, 1999). The internet is an excellent tool for communicating with individuals as it provides the opportunity to deliver specific content to a specific user on a website (Lerer, 2001). The internet has revolutionized the way in which consumers search for information and it has had an impact on the consumers' decision making process, particularly within the health care industry (Goetzinger, Park, Lee, \& Widdows, 2007). The internet provides an opportunity for personal interaction between a pharmaceutical company and the online user (Lerer, 2001).

Faced with an increasingly challenging operating environment and the ever changing technology, pharmaceutical health organisations are currently seeking unique and innovative ways to create and maintain close, sustainable relationships with consumers (Lerer, 2001). The demand for quality, information rich health websites is on the rise and consumerism is becoming a prosperous movement within the healthcare system (Ball \& Lillis, 2001). Due to the ever changing technology, consumers seeking health-related information have a larger variety of online pharmaceutical healh websites, through which they are able to access health and product information, than what was openly available in the past (Goetzinger, Park, Lee, \& Widdows, 2007). "E-health" is a term generally used to define this evolution. E-health can be defined as "the intersection of medical informatics, public health and business, referring to health services and information delivered or enhanced through the internet and related technologies." (Ball \& Lillis, 2001, p. 4)

As healthcare organisations are making a move away from a purely business-to-business orientation and devoting more time to business-to-consumer activities (Ball \& Lillis, 2001), consumers are increasingly turning to the internet for health related websites in an attempt to find information that may have been previously unavailable (Goetzinger, Park, et al., 2007). Thus, armed with the right information within various website content components, health organisations will be able to survive new technological changes and consumer demands and build a stronger relationship with consumers (Ball \& Lillis, 2001).

When the internet is used for purchasing purposes, consumers are always met by a web page created by the company. What a customer may experience from visiting a web page has been known to be one of the most vital factors for online success (Schenkman \& Jonsson, 2000). Therefore, through the creation of a compelling web experience, a consumer's purchase intention can be influenced (Constantinides, 2004). Constantinides (2002) defines the web experience as "the result of exposure to a combination of notions, emotions and impulses caused by the design and other marketing elements of the online presentation" (Constantinides, 2002).

Based on Constantinides' (2004) findings, various elements of the online experience were identified and classified into three different categories:

- Content Factors: Content factors include features that exercise a direct and powerful influence on the consumer by making the appearance of the website aesthetically positive. Also the offer to consumers is made tangible and attractive. Within the content factor, aesthetics and marketing mix factors are included. Aesthetics is composed of elements such as design, presentation quality, design elements, and style while the marketing mix factor is made up of communication, product, fulfilment, price, promotion and characteristics elements (Constantinides, 2004).

- Psychological Factors: Psychological includes trust-building features based on transaction security, customer data misuse, customer data safety, uncertainty-reducing elements, and guarantees/return policies elements. Constantinides (2004) states that it's important to ensure that websites communicate trust integrity and credibility in order to persuade customers to stop explore them, and interact online. It is possible to build trust by deploying elements that result in reducing uncertainty, guaranteeing the safety of customers' personal information and transaction data and eliminating fears of fraud (Constantinides, 2002).

- Functionality Factors: Functionality factors improve the online experience by giving the web user a functioning, easy to use search as well as an interactive website. The functionality category is composed of usability and interactivity factors. The usability factor is made up of variables that include convenience, site 
navigation, information architecture, ordering/payment process, search facilities and process, site speed and findability/accessibility. Interactivity factor is composed of customer service/ after sales, interaction with company personnel, customization and network effects elements (Constantinides, 2004).

In this study, the focus will be based mainly on marketing mix and interactive content factors utilised during the consumers web experience. Therefore, for the study to be more focused, a framework has been developed and a definition for web content is provided in the literature review. These content components were adopted from mainly the work of Verhagen, Boter, \&Adelaar (2010) as well as Constantinides (2004); Huizingh (2000); Burke (2002); Liang \& Lai (2002) and Evans \& King (1999).

\subsection{Problem Statement}

Verhagen, Boter, \& Adelaar (2010) proposed that online content may be an important predictor of online purchase intentions. A good reason for studying the impact of website content on purchase behaviour is that, the content displayed on a website is under the direct control of the pharmaceutical health shop owner and the web designer. As stated by Spiller \& Lohse (1997), shopping at an online store is similar to shopping through a print catalogue as both these involve the delivery of the purchases and in both cases, consumers are unable to touch or smell the products before making a purchase (Spiller \& Lohse, 1997). This indicates that the promise of e-commerce depends greatly on user information and consumer experiences with the online websites. Thus, the purpose of thisresearch was to determine the website content that is optimal for the healthcare industry and also understand which content factors are more important than others.

Verhagen, Boter, \& Adelaar (2010) and Burke (2002) have identified ten major content components, these components were not specific to pharmaceutical websites and health care product offering. Also, web based interactive content was not considered in the above mentioned studies. Based on this, there is not much known about the types of content specifically important for pharmaceutical health websites. In this study, the relative importance of the various content components will be measured. In accordance with information quality, information satisfaction, loyalty and purchase intention.

Within the research conducted on the literature on e-commerce, various authors have been identified who have developed theories and suggested concepts. Huizingh (2000) developed a framework that assists in distinguishing content from design elements while extensive research has been conducted on how to measure the content quality and design of websites (e.g. Madu \& Madu, 2002; Perry \& Bodkin, 2000). A similar study was done by Evans \& King (1999) where guidelines were created in order to plan, manage and assess the quality of web sites. Research conducted by Burke (2002) focused on determining what consumers require in the physical and virtual store. Several authors have suggested that the adequate use of website content is likely to depend on the products being sold as stated by Peterson, Balasubramanian, \& Bonnenberg, (1997). Most impotantly, Verhagen, Boter, \& Adelaar (2010) conducted a study that illustrates that consumers rely on different website content elements when shopping for different types of consumer products.

With respect to health related studies conducted, a number of researches have conducted studies based on the quality and value information of e-services delivered to consumers who seek health information (e.g. Goetzinger, Park, Lee, \& Widdows, 2007; Gummerus, Liljander, Pura, \& Van Riel, 2004). Also, research conducted by Ball \& Lillis (2001), focused mainly on physician web pages and building relationships between physicians and patients. Cain, SarasohnKahn, \& Wayne (2000) focused on determining the use of the internet for health-orientated content, community, commerce and care.

Across these studies, a large number of web content components have been discussed, but no study has investigated them in accordance of their importance based on the perspectives of consumers. While studies have linked interactivity to website experience and effectiveness, the most important interacive content components in relation to providing relevant healt information have not been exclusively identified.

This study examined the main content components, identifued their relation to the purchase process and the relative importance was assessed according to the perceptipon of consumers with respect to information quality, information satisfaction, loyalty and purchase intention. By this, content components that are important in developing an informative healthcare site will be provided.

\subsection{Research Objectives}

The main aim in this paper was to identify website content components that consumers perceive to be necessary in 
achieving information satisfaction which in turn influences purchase behaviour. It is important to understand the consumers' perspective of the important content components, in order to provide a healthcare website that will meet the needs and expectations of the consumer. It is vital to understand what consumers view as important if any suggestions are to be made for improving healthcare websites. It is important to note that this study is based on non-prescription health products such as beauty, wellness and health supplements. Secondly, as little is known about how the various content components affect the purchase process; the content components in association with purchase process will be linked. Then, the importance of each content component will be assessed in accordance to the perception of consumers and their purchase behaviour.

This paper addressed the following research questions;

- How do consumers currently make use of the internet?

- Which content components link to each step in the decision making process

- Which content components are important and may influence traffic flow to health websites?

\section{Theoretical Model}

The theoretical model used for this study is given is presented in figure 1 below.

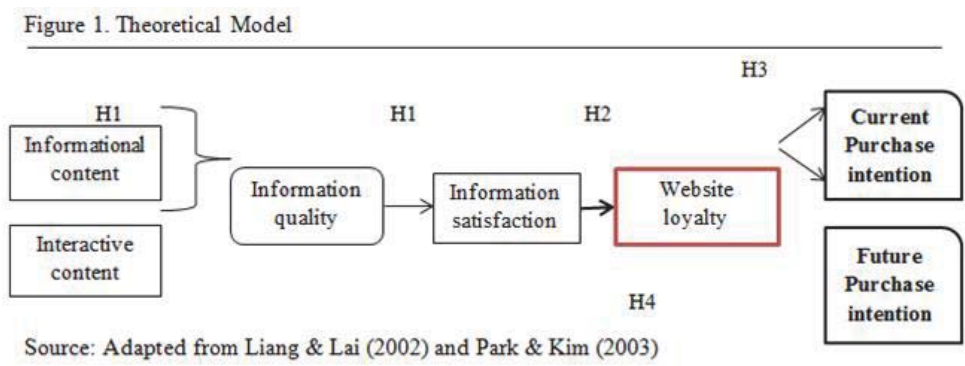

\subsection{Model Components}

Content factors refer to the features, functions information and products offered on the website (Huizingh, 2000). Content factors provide information about the services offered by the company as well as relevant information consumers seek in order to make a purchase. The decorative design and presentation of information presented online will initially draw the attention of consumer but without relevant and valuable content, consumers may venture elsewhere (Sam \& Tahir, 2008).

Information quality refers to the quality of the information within the content components retrieved from an online website (Goetzinger, Park, et al., 2007). Similarly, DeLone \&McLean (1992) define infromation quality as "the customers perception of the quality of information presented" (DeLone \& McLean, 1992, p. 66).

This construct has a relationship with information satisfaction in the sense that, once a consumer encounters online healthcare information on a website, they automatically determine the quality of the available information or, the information that they were exposed to (Goetzinger, Park ,et al., 2007) and thus, create perceptions about the quality of the online information (Galletta \& Lederer, 1989).

Information satisfaction refers to a consumer's satisfaction or dissatisfaction with the overall information encounter of an online store (Park \& Kim, 2003). This relates to the users level of satisfaction reached when navigating through the web page and content presented online. Information satisfaction online is not the same as the overall satisfaction relating to the consumers overall assessment of an organisation which is generally based on experiences and various encounters the consumer may have with a particular organisation (Jones \& Suh, 2000) yet, satisfaction in both situations is based upon the attitude and experiences of the individual.

This construct has a relationship with loyalty because according to (Lamb, Hair, et al., 2008), mere satisfaction may not continuously keep consumers from swapping to another site and making a purchase elsewhere (Bliemel \& Hassanein, 2007). Thus, loyalty to the website is looked at as a component to predicting purchase behaviour.

Website loyalty in this study refers to a positive attitudinal disposition held by a consumer towards a certain website (Jones \& Sasser, 1995). A loyal customer has the intention to maintain a relationship with a certain online website where consumers continue to explore the site and later become committed to only one site (Park \& Kim, 2003). 
This construct has a relationship with purchase intention because a loyal customer has the intention to maintain a relationship with a certain online website where consumers continue to explore the site and later become committed to only one site (Park \& Kim, 2003). This means that a loyal consumer is more likely to revisit the site and engage in repeated purchases in the future.

In summary, this model contains the constructs of information quality as having a positive influence on information satisfaction whilst information satisfaction has a positive influence website loyalty and ultimately leading to a current or future purchase.

\section{Hypotheses}

Hypotheses are statements which are formally proposed and unproven yet can be testes empirically (Malhotra \& Birks, 2007). In order to test the proposed relationships depicted in figure 1 , the following hypotheses have been put forward.

Hypothesis 1: Perceived information quality has a positive influence on information satisfaction.

Hypothesis 2: Perceived information satisfaction has a positive influence on website loyalty.

Hypothesis 3: There is a positive relationship between website loyalty and current purchase behaviour

Hypothesis 4: There is a positive relationship between website loyalty and future purchase behaviour

Hypothesis 5: There is a difference between males and females in terms of purchase intention

\section{Methodology}

The methodology and design involved in producing the research is a necessary framework in building a solid foundation from which to conduct proper empirical studies (Malhotra \& Birks, 2007). In an attempt to achieve all the objectives of the study, primary and secondary research will be undertaken.

\subsection{Sample}

The respondents were both South African men and women aged 18-40. The sample was obtained from the University of the Witwatersrand which include Wits students. In order to obtain enough information and data, as to ensure validity and reliability, the sample size consists of about 362 participants where approximately 380 people were approached. The target population include are men and women of all races, ranging in ages from 18 to 40 who are interested in pharmaceutical health products and have or intend to purchased them either in traditional stores or online. This sample is appropriate as it includes a wide variety of participants, from different backgrounds, which will give the study sufficient diversity in order to be illustrative of the broader South African population.

\subsection{Research Design}

Quantitative research is a technique which seeks to quantify the data collected (Malhotra \& Birks, 2007). This type of research technique involves the use of structured questions with predetermined response options (Malhotra, 2010). Quantitative research focuses on gathering numerical data and the results obtained are generalised from the sample to the entire population of interest (Malhotra \& Birks, 2007). Shank (2002) has defines qualitative research as a "systematic experiential analysis into meaning" (Shank, 2002, p. 5). Essentially this means that qualitative research is an investigative research design which is based on a small sample group for the purpose of obtaining an in-depth understanding of human behaviour and to provide insight governing motives, attitudes and behaviour (Malhotra \& Birks, 2007).

With the above in mind, taking both research methods into consideration, the quantitative research method has been determined to be most suitable in an attempt to assess the relationships between the variables proposed in the model.

\subsection{Data Gathering}

The first step in gathering primary data was the assembling of a questionnaire. The questionnaire contained a cover page which will briefly describe the purpose of the research. The questionnaire was based on the literature reviewed and constructed and divided into seven sections:

1. Current online consumer behaviour

2. Perceived level of information quality 
3. Perceived level of information satisfaction

4. Website loyalty

5. Purchase Intention

6. Level of importance of content components

7. General demographics

The questionnaire was only available in English only, as it is the accepted business language, even though there are eleven official languages in South Africa.

The filling in of the questionnaires was voluntary and all the information was kept confidential. All the confidential information was only seen by the researcher and the researcher's supervisor. The participants were instructed to answer all the questions accurately and honestly, otherwise those questionnaires were not incorporated in the study. The questionnaire took approximately 15 to 20 minutes to complete.

\subsection{Data Analysis}

The statistical software SAS Enterprise Guide 5.1 was used to perform the statistical analyses.

Information quality is used to predict for consumer information satisfaction. Information quality can also be used as adependent variable since the independent variables are informational and interactive content components. Perceived consumer information satisfaction can be treated as an independent variable to predict for website loyalty while website loyalty is treated as an independent variable used to predict current and future purchase behaviour.

It is vital to note that statistical significance is the critical probability in determining whether to reject or fail to reject the null hypothesis in question (Malhotra, 2010). Thus, in order to test for statistical significance, the inferential test which was used. The statistical significance was tested using a significance level of 0.05 and the $p$-value was compared against this. With respect to determining whether reject or fail to reject the null hypothesis, any $p$-value calculated to be less than the significance level of 0.05 was considered to be a significant result, thus resulting in the null hypothesis being rejected in favour of the alternate hypothesis (Malhotra, 2010).

For this research regression analysis was performed as a tool of analyses. The hypotheses was tested using linear regressions with the dependent variable being purchase intention and the predictor variables being a combination of information quality, information satisfaction and website loyalty respectively.

In order to test the reliability of this study, reliability concepts developed by Cronbach (1951) was used, which is a method that uses a reliability coefficient commonly accepted at 0.7. According to Malhotra (2010), a coefficient of 0.6 is accepted for basic research. These coefficients represent the percentage reflecting the measuring instruments true reflection of the construct that the study aims to measure.

\subsection{Reliability of the instruments used in the research}

The cronbach alpha values which were returned are indicated in table 1. This table shows that each of the constructs measured produced results higher than the desired value of 0.7 . The exceptions of this was the construct of multimedia which yielded a result of 0.65 . Although this alpha value is below 0.7 , it is still sufficient for this study as alpha values of 0.6 and above are adequate for basic research (Malhotra, 2010). 
Table 1: Cronbach Alpha Values of the Instruments Used in the Study

\begin{tabular}{|l|c|}
\hline Construct & Cronbach from data sample \\
\hline Information Quality & 0.803 \\
\hline Information Satisfaction & 0.833 \\
\hline Website Loyalty & 0.821 \\
\hline Purchase Intention & 0.920 \\
\hline Company Information & 0.781 \\
\hline Product Information & 0.776 \\
\hline Promotional content & 0.778 \\
\hline Comparison Content & 0.948 \\
\hline Help Content & 0.736 \\
\hline Advice Content & 0.843 \\
\hline Personalised Content & 0.728 \\
\hline Size assortment & 0.897 \\
\hline Unique assortment & 0.9111 \\
\hline Settlement Content & 0.870 \\
\hline Security Content & 0.898 \\
\hline Interactive Communication & 0.828 \\
\hline Customised Interactivity & 0.775 \\
\hline Transport Specific Interactivity & 0.927 \\
\hline Multimedia & 0.650 \\
\hline
\end{tabular}

\section{Results}

The demographic information collected from respondents is presented in table 2.

Table 2: Demographic composition of the sample

\begin{tabular}{|c|c|c|c|}
\hline Demographic Variable & & Frequency & Percent \\
\hline Age & $18-20$ & 169 & 56.33 \\
\hline & $21-23$ & 103 & 34.33 \\
\hline & $24-26$ & 21 & 7.00 \\
\hline & $27-29$ & 7 & 2.33 \\
\hline & $30-32$ & 0 & 0 \\
\hline Total & $33-36$ & 0 & 0 \\
\hline Gender & $37-40$ & 0 & 0 \\
\hline Total & & 300 & 100 \\
\hline & Male & 137 & 45.67 \\
\hline & Female & 163 & 54.33 \\
\hline & & 300 & 100 \\
\hline
\end{tabular}

Table 2 indicated that there were slightly more females who participated in the study compared to that of males. Table 2 also indicates that 56.33 percent of students fall between the ages of 18-20,34.33 percent of students are between the ages of 21-23, 7 percent are between the ages $24-26$ and 2.33 percent are between the ages of 27-29 which is a close reflection of the composition of students found at universities.

Table 3: Internet use statistics

\begin{tabular}{|l|c|c|c|c|}
\hline Internet access & Frequency & Percent & Cumulative frequency & Cumulative Percent \\
\hline Yes & 300 & 100 & 300 & 100 \\
\hline No & 0 & 0 & 0 & 0 \\
\hline How often internet is accessed & Frequency & Percent & Cumulative frequency & Cumulative Percent \\
\hline Once a month or less & 0 & 0 & 0 & 0 \\
\hline Once a week & 0 & 0 & 0 & 0 \\
\hline Several times a week & 49 & 16.33 & 49 & 16.33 \\
\hline Every day & 112 & 37.33 & 161 & 53.67 \\
\hline Several times a day & 139 & 46.33 & 300 & 100.00 \\
\hline
\end{tabular}


As indicated in this table, all 300 respondents have access to the internet. The main finding is that it can clearly be seen that internet usage is popular amongst university students as the students all have access to the internet. With respect to internet access, 46.3 percent of respondents access the internet several times a day while 37.33 percent access the internet daily and only 16.33 percent access the internet several times a week. The main finding derived from question 2 is that 46.33 percent of respondents who participated in the study access the internet daily on a regular basis, which indicates that almost half of the respondents access the internet more than once in one day.

Table 4: Online shopping statistics

\begin{tabular}{|l|c|c|c|c|}
\hline Online shopping & Frequency & Percent & Cumulative frequency & Cumulative Percent \\
\hline Never & 229 & 76.33 & 229 & 76.33 \\
\hline Once a week & 7 & 2.33 & 236 & 78.67 \\
\hline Once in two weeks & 9 & 3.00 & 245 & 81.67 \\
\hline Once a month & 48 & 16.00 & 293 & 97.67 \\
\hline More than once a month & 7 & 2.33 & 300 & 100.00 \\
\hline
\end{tabular}

The main finding derived from this question is that 23.66 percent $(2.33+3.00+16.00+2.33)$ of respondents who participated in the study actually make online purchases. The above finding indicates, online purchasing is increasing among students.

Table 5: Percentage of respondents who find products they are searching for

\begin{tabular}{|l|c|c|c|c|}
\hline Found products they were searching for & Frequency & Percent & Cumulative frequency & Cumulative Percent \\
\hline All (close to 100 percent) & 4 & 1.33 & 4 & 1.33 \\
\hline Most (close to 75 percent) & 9 & 3.00 & 13 & 4.33 \\
\hline Half (close to 50 percent) & 44 & 14.66 & 57 & 18.99 \\
\hline Few (close to 25 percent) & 12 & 4.00 & 69 & 22.99 \\
\hline None (close to 0 percent) & 2 & 0.67 & 71 & 23.66 \\
\hline Not applicable & 229 & 76.33 & 300 & 100.00 \\
\hline
\end{tabular}

The main finding derived from the above table is that 23.66 percent of individuals who purchase online, 14.66 percent find products they are searching for only half of the time. This indicates that many online pharmaceutical websites do not convey sufficient information within the various website content components to ensure ease and efficiency for consumers in finding what they are looking for.

Table 6: Time spent searching for information online

\begin{tabular}{|l|c|c|c|c|}
\hline Time spent searching for information & Frequency & Percent & Cumulative frequency & Cumulative Percent \\
\hline Less than 5 minutes & 3 & 1.00 & 3 & 1.00 \\
\hline 5 to 15 minutes & 19 & 6.33 & 22 & 7.33 \\
\hline 15-30 minutes & 28 & 9.33 & 50 & 16.67 \\
\hline 30-60 minutes & 16 & 5.33 & 66 & 22.00 \\
\hline More than 60 minutes & 5 & 1.67 & 71 & 23.67 \\
\hline Don't know & 0 & 0 & 71 & 23.67 \\
\hline Not applicable & 229 & 76.33 & 300 & 100.00 \\
\hline
\end{tabular}

As indicated in table 6, 16.33 percent $(9.33+5.33+1.67)$ take 15 minutes or longer to find relevant information. This shows that consumers take fairly long searching for relevant online information on websites.

\subsection{Information quality and information satisfaction}

This linear regression analysis tests the relationship between the perceived information quality and information satisfaction. This hypothesis $\left(\mathrm{H}_{1}\right)$ examines how perceived information quality has a positive influence on information satisfaction.

Null hypothesis $\mathrm{H}_{0}^{1}$ : Perceived information quality has a negative influence on information satisfaction. 
Alternate hypothesis $\mathrm{H}_{\mathrm{A}}^{1}$ : Perceived information quality has a positive influence on information satisfaction. satisfaction.

Table 7 illustrates the results of the linear regression analysis test for information quality and information

Table 7: Linear Regression Results

\begin{tabular}{|c|c|c|c|c|c|}
\hline \multicolumn{7}{|c|}{ Analysis of Variance } \\
\hline Source & DF & Sum of Squares & Mean Squares & F Value & Pr $>$ F \\
\hline Model & 1 & 52.23978 & 52.23978 & 364.60 & $<0.0001$ \\
\hline Error & 298 & 44.91430 & 0.15072 & & \\
\hline Corrected Total & 299 & 97.15407 & & & \\
\hline & CoeffVar & Root MSE & Dependent Mean & R-square & Adj R square \\
\hline & 10.49889 & 0.38823 & 3.69778 & 0.5377 & 0.5361 \\
\hline \multicolumn{7}{|c|}{ Parameter Estimates } & Prandard error & t Value & Pr $>$ F \\
\hline Variable & DF & Parameter Estimate & Stand & 13.83 & $<0.0001$ \\
\hline Intercept & 1 & 1.59376 & 0.11522 & 18.62 & $<0.0001$ \\
\hline
\end{tabular}

P-Value: The $p$-value for the model test is $<0.0001$. This $p$-value is lower than the significance level (a) which is 0.05 . Since $0.0001<0.05$, the model is significant and thus, the null hypothesis is rejected in favour of the alternate hypothesis. Here, it can be concluded that the model is significant. The null hypothesis in favour of the alternative hypothesis and concludes that a positive relationship exists between information quality and information satisfaction. This result is supported by the research which was previously done by Park \& Kim (2003), Rangnathan \& Ganapathy (2002) and Eppler, Algesheimer, \& Dimpfel (n.d)

\subsection{Information satisfaction and website loyalty}

This hypothesis $\left(\mathrm{H}_{2}\right)$ examines how perceived information quality has a positive influence on information satisfaction.

Null hypothesis $\mathrm{H}_{0}$ : Perceived information satisfaction has a negative influence on website loyalty.

Alternate hypothesis $\mathrm{H}_{A}^{2}$ : Perceived information satisfaction has a positive influence on website loyalty.

Table 8: Linear Regression results

\begin{tabular}{|c|c|c|c|c|c|}
\hline \multicolumn{7}{|c|}{ Analysis of Variance } \\
\hline Source & DF & Sum of Squares & Mean Squares & F Value & Pr $>$ F \\
\hline Model & 1 & 82.79581 & 82.79581 & 325.68 & $<0.0001$ \\
\hline Error & 298 & 75.75937 & 0.25423 & & \\
\hline Corrected Total & 299 & 158.55519 & & & \\
\hline \multicolumn{7}{|c|}{ CoeffVar } & Root MSE & Dependent Mean & R-square & Adj R square \\
\hline & 13.75531 & 0.50421 & 3.66556 & 0.5222 & 0.5206 \\
\hline \multicolumn{7}{|c|}{ Parameter Estimates } & Pr \\
\hline Variable & DF & Parameter Estimate & Standard error & t Value & Pr \\
\hline Intercept & 1 & 1.23398 & 0.13785 & 8.95 & $<0.0001$ \\
\hline Loyalty & 1 & 0.71447 & 0.03959 & 18.05 & $<0.0001$ \\
\hline
\end{tabular}

The $p$-value for the model test is $<0.0001$. This $p$-value is lower than the significance level (a) which is 0.05 . Since $0.0001<0.05$, the model is significant and thus, the null hypothesis is rejected in favour of the alternate hypothesis. Here, it can be concluded that the model is significant. The null hypothesis in favour of the alternative hypothesis and concludes that a positive relationship exists between information satisfaction and website loyalty. This result is supported by the research which was previously done by Park \& Kim (2003), Oliver, (1999), Shankar, et al., (2000), Li, Browne, \& Wetherbe (2006) which found that information satisfaction has a positive relationship with consumer loyalty and commitment. 


\subsection{Website loyalty and Current purchase intention}

This hypothesis $\left(\mathrm{H}_{3}\right)$ examines if website loyalty has a positive influence on purchase intention.

Null hypothesis $\mathrm{H}_{0}{ }^{3}$ : There is a negative relationship between website loyalty and current purchase behaviour.

Alternate hypothesis $\mathrm{H}_{A}{ }^{3}$ : There is a positive relationship between website and current purchase behaviour.

Table 9: Linear regression Results

\begin{tabular}{|c|c|c|c|c|c|}
\hline \multicolumn{7}{|c|}{ Analysis of Variance } \\
\hline Source & DF & Sum of Squares & Mean Squares & F Value & Pr>F \\
\hline Model & 1 & 55.97636 & 55.97636 & 157.04 & $<0.0001$ \\
\hline Error & 298 & 106.22031 & 0.35644 & & \\
\hline Corrected Total & 299 & 162.19667 & & & \\
\hline & CoeffVar & Root MSE & Dependent Mean & R-square & Adj R square \\
\hline & 17.54249 & 0.59703 & 3.40333 & 0.3451 & 0.3429 \\
\hline \multicolumn{7}{|c|}{ Parameter Estimates } & Pr $>$ F \\
\hline \multicolumn{7}{|c|}{ Parameter Estimate } & Standard error & t Value & $<0.0001$ \\
\hline Variable & DF & 2.23144 & 0.09967 & 22.39 & $<0.0001$ \\
\hline
\end{tabular}

P-Value: The $p$-value for the model test is $<0.0001$. This $p$-value is lower than the significance level $(a)$ which is 0.05 . Since $0.0001<0.05$, the model is significant and thus, the null hypothesis is rejected in favour of the alternate hypothesis. Here, it can be concluded that the model is significant.

\subsection{Website loyalty and Future purchase intention}

This hypothesis $\left(\mathrm{H}_{4}\right)$ examines if website loyalty has a positive influence on purchase intention.

Null hypothesis $\mathrm{H}_{0} 4$ : There a negative relationship between website loyalty and future purchase intention.

Alternate hypothesis $\mathrm{H}_{A}^{4}$ : There is a positive relationship between loyalty and future purchase intention.

Table 10: Linear Regression for $\mathrm{H}^{4}$

\begin{tabular}{|c|c|c|c|c|c|}
\hline \multicolumn{7}{|c|}{ Analysis of Variance } \\
\hline Source & DF & Sum of Squares & Mean Squares & F Value & Pr $>$ F \\
\hline Model & 1 & 57.91030 & 57.91030 & 165.48 & $<0.0001$ \\
\hline Error & 298 & 104.28637 & 0.34995 & & \\
\hline Corrected Total & 299 & 162.19667 & & & \\
\hline & CoeffVar & Root MSE & Dependent Mean & R-square & Adj R square \\
\hline & 17.38206 & 0.59157 & 3.40333 & 0.3570 & 0.3549 \\
\hline \multicolumn{7}{|c|}{ Parameter Estimates } & Pr $>$ F \\
\hline Variable & DF & Parameter Estimate & Standard error & t Value & $<0.0001$ \\
\hline Intercept & 1 & 2.18082 & 0.10099 & 21.60 & $<0.0001$ \\
\hline
\end{tabular}

P-Value: The $p$-value for the model test is $<0.0001$. This $p$-value is lower than the significance level (a) which is 0.05 . Since $0.0001<0.05$, the model is significant and thus, the null hypothesis is rejected in favour of the alternate hypothesis. Here, it can be concluded that the model is significant. The researcher rejects the null hypothesis for both $\mathrm{H}^{4}$ and $\mathrm{H}^{5}$ in favour of the alternative hypothesis and concludes that a positive relationship exists between website loyalty and current and future purchase behaviour respectively. This result is supported by the research which was previously done by Sam \& Tahir (2008) as they have suggested that the purchase intention of a consumer is linked loyalty as a consumer develops an online relationship and makes transactions with a certain web retailer. Additionaly, this finding is consistent with the statement provided byPrichard, Havitz, \& Howard (1999) stating that commitment plays a key role in the formation of a consumers' loyalty as loyalty leads to behavioural intention (Prichard, Havitz, \& Howard, 1999). 


\section{Conclusions}

The following conclusions pertain to the effect that the individual variables has had on online purchase behaviour.

\subsection{Information quality}

Information quality refers to the quality of the information within the content components retrieved from an online website(Goetzinger, Park, Lee, \& Widdows, 2007). This construct centres on the consumers perceived level of quality of the information provided based on dimensions such as relevance, currency, sufficiency, understandability, consistency, and playfulness (interest) (Bliemel \& Hassanein, 2007). This study therefore examined whether or not the perceived information quality from website content had a positive relationship with information satisfaction which was the first hypothesis $\left(\mathrm{H}^{1}\right)$. Through the regression analysis conducted, it was shown that the null hypothesis was rejected in favour of the alternative hypothesis and it was found that the information within content components which was found to be of high quality resulted in consumer information satisfaction.

\subsection{Information satisfaction}

The construct of information satisfaction in the context of this study refers to the users level of satisfaction reached when navigating through the web page and their assessment of the content presented online and whether the website satisfies the consumers' expectations. Therefore, this study examined whether there is a positive relationship between information satisfaction and website loyalty which is the second hypothesis $\left(\mathrm{H}^{2}\right)$.

Through the regression analysis which was conducted this hypothesis was confirmed and it was found that information satisfaction derived from the consistent quality of the information provided had a positive influence on the website loyalty of a consumer.

\subsection{Website loyalty}

This research examined website loyalty in terms of a consumer's positive attitudinal disposition held towards a certain website. In the context of this study, loyalty refers to how likely the consumer is to return to the pharmaceutical health website and continuously refer to the site for health information. This study examine whether there was a positive relationship between website loyalty and the current and future purchase intentions of consumers which were the third $\left(\mathrm{H}^{3}\right)$ and the fourth $\left(\mathrm{H}^{4}\right)$ hypotheses respectively.

Through the regression analysis which was conducted these hypothesis was confirmed and it indicated that website loyalty positively affects current and future purchase behaviour of consumers.

\subsection{Purchase intention}

Through the regression analyses conducted it can be concluded that information quality positively affects information satisfaction which then positively affects website loyalty and thus, the online purchase intention of consumers is positively affected both currently and in the future.

\section{Recommendations}

The study shows that when it comes to the component of purchase behaviour, consumers are significantly affected by the different types of content components incorporated into a webpage. Within these content components, consumers view quality information as more valuable as they are informed about products more effectively, relevant to their needs. This then influences the consumers' information satisfaction. Once the consumer is satisfied with the information provided through the relevant content components, loyalty towards the firm is developed due to the consistent quality of the content thus, resulting in purchase behaviour. This shows that it is important for online health websites to provide relevant, quality information within website content components most suitable in assisting consumers in making an online purchase.

This study provides several implications for marketers. This study is useful for marketers in the healthcare industry as marketing communications provided by the interactive website components serves as marketing communications and allows consumers to engage in interactive communication with organisations in a more cost effective manner than ever 
before. These communications allow for the development of close relationships where the marketer is able to determine customer future needs and wants.

A key characteristic of the internet is that users are totally in control of which websites they visit and the amount of time they choose to remain online. Therefore basic informational content which provides the user with assistance should be provided, such as an online help desk, content that assists in making a purchase and a keyword search.

Pharmaceutical health websites should allow for interactive communication through emails, online consultation sessions and an online customer inquiry option in order to take full advantage of the utility and economy of the internet as a medium for communication. This may prove to be successful as many site visitors may have had previous exposure to the health organisation either through a sale, promotion, or a traditional in-store experience and will therefore visit the website to obtain additional information instead of contacting the company for the first time.

Pharmaceutical health websites should make better use of their websites as a medium for informing customers about the organisations range of products as well as services offered. The study found that individuals who participated in the study feel that contact information and information providing customer service hours were important. Thus, the provision of informational content such as the above mentioned would be helpful to prospective customers and could possibly encourage sales.

Vital information such as online notifications about the status of the delivery, online quotations and the ability to track an order online should never be absent from an e-commerce pharmaceutical health website as these have been found to be quite important to users. Online tracking or online notifications will provide consumers with information about when to expect purchases to arrive. This will thus provide satisfaction to the customer and a loyal relationship between the consumer and online pharmaceutical health website can be built thus, resulting in an increase in sales.

\section{Limitations}

Due to time and monetary constraints, convenience sampling was used which may impact the generalizability of the research. Thus, the results of this study may not be appropriate for generalizing all health online shoppers as university students may not be as interested and involved in healthcare as older individuals would be. However, understanding one segment (youth), it may be beneficial to marketing practitioners the determination of future needs and wants of customers.

Also, as customer demands continue to rise and the availability of informational and interactive content continues to increase thus, the standard for acceptable and appropriate content will continue to rise and alter due to technological advances.

Another limitation centres on the amount website content components examined. This study was limited to only a select number of content components where there are certainly many other content components that that provide information and may also have impact on the online purchase behaviour of consumers.

\section{Future Research}

The context of online content has many possibilities which may leave room for future research to branch into new areas of knowledge in order to extend the findings of this research. It is generally reasonable to assume that other e-commerce markets may react differently to the website content components identified in this study. For example, background music may be more important to online music stores than online health pharmaceutical companies thus, investigating pharmaceutical market behaviour could improve the understanding managers have in attracting and retaining potential customers to online websites through the online content provided.

\section{References}

Ball, M. J., \& Lillis, J. (2001). E-health: Transforming the physician/ parient relationship. International Journal of Medical Informatics, 61, $1-10$.

Bliemel, M., \& Hassanein, K. (2007). Consumer Satisfaction with Online Health Information Retrieval: A Model and Empirical study. eService Journal, 5(2), 54-84.

Burke, R. R. (2002). Technology and the consumer interface: What consumers want in the physical and virtual store. Journal of the Academy of Marketing Science, 30(4), 411-432.

Butler, P., \& Peppard, J. (1998). Consumer purchasing on the internet: Process and prospects. European Management Journal, 16(5), 600-610.

Cain, M. M., Sarasohn-Kahn, J., \& Wayne, J. C. (2000). Health e-people: The online consumer experience. California HealthCare 
Foundation, 1-63.

Constantinides, E. (2002). The 4S web-marketing mix model. Electronic Commerce Research and applications, 1, 57-76.

Constantinides, E. (2004). Influencing the online consumer's behavior: The web experience. Internet Research, 14(2), 111-126.

Creswell, J. (1994). Research Design: Qualitative \& Quantitative Approaches, (2nd ed.). London: SAGE Publications.

De Lanerolle, I. (2012). The new wave: Who connects to the internet, how they connect and what they do when they connect. South African Network Society Project, University of Witwatersrand, 1-28.

DeLone, W., \& McLean, E. (1992). Information system success: The quest for the dependent variable. Information Systems Research, 13(1), 60-95.

Ellinger, A. E., Lynch, D. F., Andzulis, J. K., \& Smith, R. J. (2003). B-to-B E-commerce: A content analytical assessment of motor carrier websites. Journal of Business Logistics, 24(1), 199-220.

Eppler, M. J., Algesheimer, R., \& Dimpfel, M. (2003). Quality criteria of content driven websites and their influence on customer satisfaction and loyalty: An empirical test of an information quality framework. Proceedings of the English International Conference on Information Quality, 108-120.

Evans, J. R., \& King, V. E. (1999). Business-to-business marketing and the world wide web: Planning, managing and assessing web sites. Industrial Marketing Management, 28, 343-358.

Galletta, D. F., \& Lederer, A. L. (1989). Some cautions on the measurement of user information satisfaction. Concepts, Theory and Techniques, 20, 419-435.

Gates, B. (1996, March 1). Content is king. Retrieved March 5, 2013, from www.craigbaily.net

Goetzinger, L., Park, J., Lee, Y. J., \& Widdows, R. (2007). Value-drive consumer e-health information search behaviour. International Journal of Pharmaceutical and Healthcare Marketing, 1(2), 128-142.

Gummerus, J., Liljander, V., Pura, M., \& Van Riel, A. (2004). Customer loyalty to content based websites: The case of online health care services. Journal of Service Marketing, 18(3), 175-186.

Huizingh, E. K. (2000). The content and design of web sites: An empirical study. Information and Management, 37, 123-134.

Jones, M., \& Suh, J. (2000). Transaction specific satisfaction: An empirical analysis. Journal of Service Marketing, 14(2), 147-159.

Jones, T., \& Sasser, E. (1995). Why satisfied customers defect. Harvard Business Review, 73, 88-99.

Lamb, C. W., Hair, J. F., McDaniel, C., Boshoff, C., \& Terblanche, N. S. (2008). Marketing (Third edition ed.). Cape Town: Oxford University Press Southern Africa.

Lerer, L. (2001). Pharmaceutical marketing segmentation in the age of the internet. International Journal of Medical Marketing, 2(2), 159166.

Liang, T.-P., \& Lai, H.-J. (2002). Effect of store design on consumer purchases: An empirical study of on-line bookstores. Information and Management, 39, 431-444.

Liebermann, Y., \& Stashevsky, S. (2002). APercieved risks as barriers to the internet and e-commerce usage. Qualitative Market Research: An Internatioinal Journal, 5(4), 291-300.

Madu, C. N., \& Madu, A. A. (2002). Dimensions of e-quality. International Journal of Quality and Reliability Management, 9(3), 246-258.

Malhotra, N., \& Birks, D. (2007). Marketing Research: An Applies Approach (3rd ed.). Harlow, England: Prentice Hall.

Malhotra. (2010). Marketing Research: An Applied Orientation (6th ed.). New Jersey: Pearson.

Oliver, R. (1999). Whence consumer loyalty. Journal of Marketin, 63(4), 33-44.

Park, C.-H., \& Kim, Y.-G. (2003). Identifying key factors affecting consumer purchase behaviour in an online shopping context. International Journal of Retail and Distribution Management, 31(1), 16-29.

Perry, M., \& Bodkin, C. (2000). Content analysis of fortune 100 company web sites. Corporate Communications: An International Journal, 5(2), 87-96.

Peterson, R. A., Balasubramanian, S., \& Bonnenberg, B. J. (1997). Exploring the implications of the internet for consumer marketing. Journal of the Academy of Marketing Science, 25(4), 329-346.

Rangnathan, C., \& Ganapathy, S. (2002). Key dimensions of business-to-consumer websites. Information and Management, 39, 457465.

Sam, M. F., \& Tahir, N. H. (2008). Website Quality And Consumer Online Purchase Intention Of Air Ticket. International Journal of Basic \& Applied Sciences, 9(10), 20-28.

Schenkman, B. N., \& Jonsson, F. U. (2000). Aesthetics and preferences of web pages. Behaviour and Information Technology, 19(5), 367-377.

Shank, G. (2002). Qualitative Research: A personall skills approach (2nd ed.). New Jersey: Merril Prentice.

Spiller, P., \& Lohse, G. (1997). A classification of internet retail stores. International Journal of Electronic Commerce, 2, 29-56.

van der Heijden, H., \& Verhagen, T. (2004). Online store image: conceptual foundations and empirical measurement. Information and Management, 41, 609-617.

Verhagen, T., Boter, J., \& Adelaar, T. (2010). The effect of product type on consumer preferences for website content elements: An empirical study. Journal of Computer-Mediated Communication, 16, 139-170.

Yates, R. A., \& Noyes, J. M. (2007). Web site design, self-monitoring style and consumer preference. Journal of Applied Social Psychology, 37(6), 1341-1362.

Zwass, V. (1996). Electronic Commerce: Structures and Issues. International Journal of Electronic Commerce, 1(1), 3-23. 